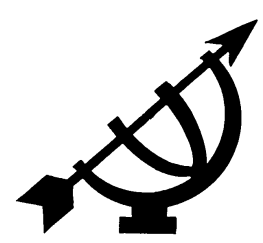

\title{
Ses dekades opvoedingsfilosofie sedert J. Chris Coetzee - waar staan ons vandag?
}

\author{
J.L. van der Walt \\ Fakulteit Opvoedingswetenskappe \\ Potchefstroomkampus \\ Noordwes-Universiteit \\ POTCHEFSTROOM \\ E-pos: jlvdwalt@intekom.co.za
}

\begin{abstract}
Six decades of philosophy of education since J. Chris Coetzee where do we stand today?

Approximately six decades have gone by since Professor J. Chris Coetzee first published his "Introduction to the philosophy of education" (the title of which can be translated as "Introduction to general theoretical education"). This article is aimed at explaining how the field of reformational philosophy of education in South Africa has developed during these six decades. The discussion does not follow the pattern of a mere historical review of events in the field. Use is made of recent developments in the fields of the history and sociology of science to explain the condition that philosophy of education in South Africa currently finds itself. Theories about the evolution of science developed by Kuhn, Neurath, Barrow and others are used to explain the nature of the crises experienced in this field of science.
\end{abstract}

\section{Opsomming}

Ses dekades opvoedingsfilosofie sedert J. Chris Coetzee - waar staan ons vandag?

Ses dekades het verloop sedert professor J. Chris Coetzee die eerste keer sy "Inleiding tot die algemene teoretiese opvoedkunde" gepubliseer het. Hierdie artikel het ten doel om te verduidelik hoe die reformatoriese opvoedingsfilosofie in Suid-Afrika in hierdie ses dekades ontplooi het. Die bespreking is nie in die vorm van 'n blote oorsig van gebeure nie. Aan die hand van onlangse insigte op die terreine van die filosofie en 
die sosiologie van die wetenskap word verduidelik waarom die reformatoriese opvoedingsfilosofie in Suid-Afrika tans in die staat verkeer waarin dit wel is. Teorieë oor die ontplooiing van die wetenskap ontwikkel deur Kuhn, Neurath, Barrow en andere word gebruik om die aard van die krisisse wat hierdie vakgebied ondervind, te verduidelik.

\section{Inleiding en doel van die bestekopname}

J. Chris Coetzee het in 1943 die tweede deel van sy bekende Inleiding tot die opvoedkunde onder die titel Inleiding tot die algemene teoretiese opvoedkunde die lig laat sien. Hierdie werk volg op verskeie ander van hom met 'n opvoedingsfilosofiese strekking, waaronder Die gereformeerde beginsel en die onderwys in Transvaal, 1859-1937 (1939); Die moderne opvoeding: 'n histories-kritiese studie (1939) en Die eerste beginsels van die Calvinistiese opvoeding (1940). Na die publikasie van die vermelde Inleiding tot die algemene teoretiese opvoedkunde publiseer hy nog verskeie ander met 'n opvoedingsfilosofiese inslag, soos gemerk kan word in die bibliografie in Van der Walt en Du Toit (1992:37-38).

In die ses dekades wat verloop het sedert Coetzee sy Inleiding tot die algemene teoretiese opvoedkunde gepubliseer het, het die reformatoriese opvoedingsfilosofie 1 hier te lande, en ook elders in die wêreld op besondere maniere ontplooi tot waar dit vandag is. Die doel van hierdie besinning is nie om slegs die feite in verband met hierdie ontplooiing neer te pen nie. Dit sou, in wetenskapsfilosofiese en -sosiologiese sin, nie interessant wees nie. Die "subteks" van die oorsig en bestekopname wat hierna volg, is dus om aan die hand van enkele nuwere insigte op die terrein van die wetenskapsfilosofie en -sosiologie, te toon hoe die wetenskap in die praktyk neig om te ontplooi. Hierdie insigte word toegelig met voorbeelde uit die beoefening van die opvoedingsfilosofie in die ses dekades sedert Coetzee se Inleiding in die algemene opvoedingsfilosofie. Deur hierdie werkwyse te volg, kan die besinning interessant en stimulerend vir nie-opvoedingsfilosowe wees - dit

1 Die aandag word daarop gevestig dat hierdie besinning oor die beoefening van die opvoedingsfilosofie as wetenskap handel. Die fokus is dus deurentyd op aspekte van wetenskapsbeoefening (die beoefening van die opvoedingsfilosofie) en nie op aspekte van opvoeding self (dit wil sê, die opvoedingsfilosofie as sodanig) nie. Ruimte laat nie toe dat die implikasies van paradigmatiese raamwerke of episteme vir byvoorbeeld die kurrikulum, die aard van die skool, die aard van onderrig, die mensbeskouing, ensovoorts aangetoon kan word nie. 
kan hulle in staat stel om die impak van resente wetenskapsteoretiese insigte op hulle eie kennisgebiede te beoordeel. 2

\section{Coetzee se opvoedingsfilosofiese bydrae in die kader van 'n Calvinistiese paradigma of episteem}

Ten tye van Coetzee se aktiewe beoefening van die opvoedkunde (hy het vanaf 1953 tot met sy aftrede in 1964 gedien as rektor van die destydse Potchefstroomse Universiteit vir $\mathrm{CHO}$ ) en tot in die 1970's, was die positivistiese siening gangbaar dat die wetenskap kumulatief werk: daar is gemeen wetenskaplikes is in staat om net al meer en meer waarhede aangaande die werklikheid bloot te lê. Die groei van die wetenskap is dus kontinu: dit is 'n versameling van al meer feite en die inpassing van al meer verskynsels onder al minder wetmatighede of reëls (Fuller, 1993:101). Die besef onder positiviste dat hierdie 'n naïewe beeld van die wetenskap is, en dat wetenskaplikes soms hulle vorige beskouings verwerp, het na hulle mening nie afbreuk gedoen aan die basiese optimisme oor wat die wetenskap kan vermag nie - ou beskouings word slegs laat vaar ten einde beteres in hulle plek te plaas (Mautner, 2000:300).

Kuhn ([1962] 1973) se histories-sosiologiese ontleding van die ontplooiing van die wetenskap het hierdie optimistiese en kumulatiewe opvatting oor die wetenskap van die positiviste bedreig. $\mathrm{Hy}$ was onder meer van mening dat die wetenskap met rukke en stote, dus diskontinu, ontplooi (Fuller, 1993:101). Volgens hom aanvaar 'n groep wetenskaplikes, onder meer as gevolg van hulle opleiding, en selfs weens dogmatiese inisiasie in die wetenskap, die een of ander paradigma ${ }^{3}$ as die vanselfsprekende raamwerk

Duidelikheidshalwe moet onderstreep word dat die bestekopname slegs oor die beoefening van die reformatoriese opvoedingsfilosofie in Suid-Afrika handel. Ander belangrike wetenskapsfilosofiese verwikkelinge met betrekking tot die opvoedingsfilosofie word slegs terloops ter sprake gebring.

$3 \quad$ Kuhn (1962/1973:43 e.v.) gebruik die term paradigma in 'n wye verskeidenheid betekenisse (vgl. Godfrey-Smith, 2003:75-79). Soms bedoel hy daarmee 'n stel commitments, ander kere gebruik hy dit om te dui op 'n werklikheidsbeeld, dan weer gebruik hy dit vir wetenskaplike tradisies of denkraamwerke. Volgens Godfrey-Smith (2003:76) wil dit voorkom of Kuhn voorkeur geskenk het aan 'n "losser" of meer algemene betekenis, naamlik dat 'n paradigma dui op 'n omvattende manier van wetenskapsbeoefening. Hy het later, in reaksie op sy kritici, die betekenis daarvan afgeperk tot "dissiplinêre matriks" (vgl. Kuhn, 1973). Dit sal mettertyd uit die uiteensetting in hierdie artikel duidelik word dat Coetzee en sy medestanders se werk nie in die konteks van 'n dissiplinêre matriks geplaas kan word nie, maar eerder in dié van paradigma as omvattende denkraamwerk. Paradigma het hier dus eerder die betekenis van 'n episteem in 
waarbinne hulle die wetenskap beoefen. In sommige gevalle dwing hulle selfs die werklikheid om in die raam van die paradigma in te pas, onder meer deur slegs raaisels en probleme wat deur die paradigma opgewerp word, te ondersoek. Ander probleme bly dan buite hulle gesigsveld. Vir so 'n groep is hierdie "normale wetenskapsbeoefening" (Mautner, 2000:300; Van den Beukel, 2000:13-16).

'n Mens kan die werking van so 'n wetenskaplike paradigma toelig aan die hand van Coetzee cum suis se opvoedingsfilosofiese arbeid. Hy beoefen die opvoedkunde in die raamwerk van 'n paradigma of episteem wat bekend staan as "die Calvinisme"4. Dit is

die sin wat Michel Foucault dit gebruik het in sy Les Mots et les Choses (Die orde van dinge) (1966): 'n histories-gefundeerde struktuur van denke wat die voorwaardes en die grense bepaal vir dit wat gedink en gesê kan word binne 'n sekere sosiale en intellektuele opset. 'n Episteem is dus 'n tyds- en kultuurbepaalde diskoersraamwerk. Dit is die onderliggende netwerk wat die denke toelaat om homself te orden. Dit beperk die totaliteit van ervaring, kennis en waarheid, en bepaal die aard van die wetenskapsbeoefening in 'n bepaalde tydsgewrig. In 'n sekere sin, meen Horrocks en Jevtic (2004:65), het Foucault dus die paradigmagedagte van Kuhn met hierdie benadering in 'n nuwe vorm gegiet. Volgens Blake (1996:219) is 'n episteem dan "die gestruktureerde versameling van ons diepste en mins geredelik bevraagtekende filosofiese veronderstellings. Dit is uitgangspunte of veronderstellings wat nie sterk geartikuleer of geformuleer is nie, maar tog vorm hulle 'n onopvallende dog bepalende en determinerende kulturele raamwerk vir 'n persoon se diepste denke". Foucault (1996) gebruik 'n hele aantal uitdrukkings om inhoud te gee aan die term episteem: interpretatiewe diagram (p. 101), "a regime of practices" (p. 103), "a polyhedron of intelligibility" (p. 105), teoretiese skemas (p. 105), "a structure of understanding" (p. 108), rasionele skemas (p. 109), om maar net enkeles te noem. "Die Calvinisme" waarin en waarmee Coetzee en sy medestanders gewerk het, is in wese so 'n episteem. Volgens Foucault (1996:109) bied die Calvinisme, soos ander episteme, "general principles that are not all present in the thoughts of the individuals whose concrete behavior is nevertheless to be understood on their basis".

$4 \quad$ Vir 'n volledige uiteensetting van "die Calvinisme", vgl. De Klerk (1973:157-172). De Klerk (1973:160) wys onder andere daarop dat die Calvinistiese lewensbeskouing in Suid-Afrika ook die naam "Christelik-nasionaal" gekry het, wat daarop neerkom dat alles van die volkshuishouding volgens Christelike beginsels ingerig en beoordeel word. Hy wys verder daarop dat, alhoewel die Calvinisme gedurende die 18de en 19de eeue in Suid-Afrika baie verdring was, daar altyd 'n kerngroep was wat deur die krag van hulle oortuiging en stryd soos 'n suurdeeg gewerk het, sodat die Calvinisme gedurende die tweede helfte van die 19de eeu en in die 20ste eeu 'n sterk beslag in Suid-Afrika gekry het. Ruimte laat nie toe dat hierdie paradigma in besonderhede hier uiteengesit word nie. Vir die hoofelemente daarvan, vergelyk De Klerk (1973:159), ook De Klerk en Duvenage (1973) en Duvenage en De Klerk (1973). Dit is binne hierdie denkraamwerk of paradigma wat Coetzee en sy geesgenote gewerk het. In 'n sekere sin het hierdie denkraamwerk of paradigma die aanhangers daarvan in 
'n reformatoriese raamwerk gedefinieer deur die nalatenskap van teoloë en filosowe soos Augustinus, Calvyn, Kuyper, Bavinck, Dooyeweerd, Vollenhoven, Stoker en vele andere. Die raamwerk is ook gefundeer in die Drie Formuliere van Eenheid van die reformatoriesgesinde kerke. Weens die aard van hierdie raamwerk dink Coetzee oor die opvoeding en die opvoedkunde in die lig van die Bybel as die Heilige Woord van God, en huldig hy Skriftuurlike oortuigings aangaande God, die werklikheid, die mens en die wetmatighede in die skepping (ooreenkomstig sy reformatoriese lewensopvatting) (Bingle, 1953; Snyman, 1953). Coetzee fokus as gevolg van hierdie paradigma op 'n reformatoriese opvoedingsleer, en bestee weinig aandag aan die ontisiteit van die opvoedingsverskynsel as algemeen voorkomende verskynsel, ook onder nieChristene. Coetzee bou self ook verder aan hierdie paradigma: meer as 100 meestersgraad- en meer as 60 doktorsgraadstudente behaal hulle kwalifikasies in die opvoedkunde onder sy leiding/ promotorskap.

Coetzee en sy opvolgers (Bingle, Schutte, Van Wyk en Van der Walt) se werk kan ook met verskillende ander metafore uit die wetenskapsfilosofie toegelig word. Barrow (1999:60 e.v.) vergelyk wetenskaplike werk soos hierdie met die ontdekking van die klipblokke van 'n groot gebou wat onder die sand toegewaai geraak het. 'n Kundige opvoedingsfilosoof soos Coetzee lei sy studente en sy kollegas om die verskillende klipblokke oop te grawe en hier en daar op mekaar te plaas om sodoende op sinvolle wyse deelkonstruksies van die gebou van die wetenskap te maak. Sommige knap studente bou hele mure van die wetenskapsgebou op hierdie manier. Gaandeweg bring hierdie gemeenskap van opvoedingsfilosowe iets van die totale opvoedingsfilosofiese gebou tot stand. Hierdie werk kan ook met die wortels, stam en takke van 'n boom vergelyk word. Die punt van vergelyking is dat die wetenskap 'n lewende organisme is. Die invloed van Coetzee op sy studente en sy opvolgers kan ook geïllustreer word met die perkolasie-metafoor wat Barrow (1999:63) gebruik: kragtige opvattings van Coetzee is oorgeneem deur sy studente en verder uitgevoer en gedissemineer. Hierdie perkolerende invloed van Coetzee op die praktyk van die onderwys in Suid-Afrika tot vandag toe, sal seker nooit volledig na trefkrag, waarde en omvang geskat kan word nie.

staat gestel om, onder meer, die sogenaamde rasseprobleem van Suid-Afrika te hanteer. 
Volgens Kuhn se beskouing oor hoe die wetenskap ontplooi, is diegene wat binne 'n bepaalde paradigma werk, geneig om nie aandag te gee aan ontwikkelings buite hulle eie denkraamwerk nie. 'n Mens bemerk hierdie neiging ook by Coetzee en sy onmiddellike opvolgers, Bingle en Schutte, asook medestanders van hom soos Keyter en Fourie (UOVS). 'n Mens verneem by hulle weinig aangaande die bydraes van tydgenootlike fenomenoloë soos Oberholzer (uit wie se pen Inleiding in die prinsipiële opvoedkunde en 'n Prolegomena van 'n prinsipiële pedagogiek onderskeidelik in 1954 en 1968 verskyn het) en Langeveld (Beknopte theoretische paedagogiek, 1965), om maar enkeles te noem (vgl. ook Van Rensburg, Landman \& Bodenstein, 1994:123, 155). 5

\section{Die reformatoriese opvoedingsfilosofie in 'n krisis}

Volgens Kuhn ([1962] 1973:52 e.v.) se opvatting oor hoe die wetenskap "werk" en ontplooi, kom elke paradigma op die een of ander stadium in 'n krisis. Dit gebeur as onopgeloste probleme begin toeneem, en die betrokke wetenskaplikes vertroue in die paradigma begin verloor. Wanneer dit gebeur, breek daar 'n tydperk van "ongewone" of "revolusionêre" wetenskap aan. Niks word meer as vanselfsprekend aanvaar nie, en alternatiewe paradigmas word ondersoek. Omdat sommige probleme in terme van nuwe paradigmas opgelos kan word, begin sommige wetenskaplikes werk in die raamwerk van 'n nuwe paradigma. Op hierdie manier begin 'n nuwe tydvak van "normale wetenskapsbeoefening" tot stand kom. Nuwe paradigmas, meen Kuhn, is nie noodwendig beter as die voriges nie; hulle is net anders. Die wetenskap is dus nie noodwendig kumulatief soos die positiviste gemeen het nie, maar word uitgebou deur 'n opeenvolging van paradigmas wat incommensurable (onderling onvergelykbaar) is (Mautner, 2000: 301). Hoewel die oorgange tussen die opeenvolgende paradigmas diskontinu is, is daar op die lang duur tog netto epistemiese groei (Fuller, 1993:101).

Die opvoedingsfilosofie het ná Coetzee ook sulke krisisfases deurgegaan. Die godsdiensopvoedkundige Jan $\mathrm{H}$. van Wyk, wat vroeg in die 1970's aan die PU vir CHO as professor aangestel is, eers vir onderrig in die Wetenskapsleer en daarna as opvoedingsfilosoof, het weens sy kontak met Pretoriase en

\footnotetext{
$5 \quad$ Volledigheidshalwe moet vermeld word dat die omgekeerde - om dieselfde rede, naamlik weens die dwang van die betrokke wetenskaplike paradigma of episteem - ook plaasgevind het.
} 
Stellenboschse opvoedkundiges tot die gevolgtrekking gekom dat die reformatoriese opvoedingsfilosofie 'n vernuwing behoort te ondergaan. 6 Hoewel van Wyk in Religie, opvoedkunde en opvoeding, wat in 1973 die lig gesien het, en in verskeie ander (vgl. bronnelys by Van der Walt \& Dekker, 1983), nog steeds duidelik op die standpunt van 'n reformatoriese opvoedkunde gestaan het, het hy ook onder die besef gekom dat rekening gehou moet word met die bydraes van die fenomenologiese opvoedkundiges, onder meer die vermelde Langeveld en Oberholzer, asook Perquin, Landman, Kilian, Van Vuuren, Gunter en verskeie ander. Om hierdie rede skryf hy 'n kort beoordeling van die eksistensialisme en die fenomenologie (soos later opgeneem in Van Wyk, 1979:102 e.v.).

Hoewel Van Wyk van mening was dat die paradigma van reformatoriese opvoedkundebeoefening uitgebrei moes word met kennisname van die bydraes van sowel die eksistensialisme as die fenomenologie, en aandag aan die ontiese status van die opvoedingsverskynsel as sodanig, was hy 'n openlike en aktiewe teenstander van hierdie denkrigtings weens hulle gewaande lewensbeskoulike neutraliteit. Hy is in hierdie pogings daadwerklik ondersteun deur onder andere Schoeman, opvoedingsfilosoof verbonde aan die UOVS (vgl. Schoeman, 1975), en Heiberg van die destydse Universiteit van die Noorde. Die beoefening van die reformatoriese opvoedingsfilosofie is in die sewentigerjare van die vorige eeu gekenmerk deur lewendige debatte tussen die sogenaamde fenomenoloë aan die een kant, en die Christelike opvoedkundiges aan die ander kant. Hierdie debat het enersyds daartoe gelei dat die fenomenoloë mettertyd aandag begin gee het aan die Christelike opvoedingsleer (vgl. Landman \& Roos, 1973; Landman, 1974; Landman, Roos \& Van Rooyen, 1974), wat hulle as nawetenskaplik beskou het. Omgekeerd het dit ook daartoe gelei

Die saad vir hierdie krisis in die Calvinistiese benadering tot die opvoedkunde is reeds vroeg gesaai. In teenstelling met die heersende positivistiese denkraamwerk, en ook die fenomenologiese vertrekpunte van die PretoriaStellenbosch-skool van fenomenoloë in die opvoedkunde, wat die neutraliteitspostulaat as 'n kernaspek van goeie wetenskapsbeoefening beskou het, het Coetzee en sy medestanders geen neutraliteit in hulle wetenskapsbenadering geduld nie. Die opvoedingsverskynsel is eksplisiet vanuit 'n Christelike, dit is, Bybelse perspektief, benader. Om hierdie rede is hulle onder meer van gebrek aan wetenskaplike objektiwiteit en selfs van onwetenskaplikheid beskuldig. Van Wyk het hierdie toedrag van sake as 'n krisis in die reformatoriese opvoedkundebeoefening beskou. Na sy oordeel het die Coetzee c.s.-paradigma of -episteem nie voldoen aan die eise van die nuwe omstandighede nie. Veral die gebrek aan ontologiese analises van die opvoedingsverskynsel is as 'n tekortkoming aangevoel. 
dat die reformatoriese opvoedingsfilosowe 'n oog begin kry het vir besinning oor die ontiese status van die opvoedingsverskynsel (vgl. Van der Walt \& Dekker, 1983:106 e.v.).

'n Verdere krisis waarin die reformatoriese opvoedingsfilosofiebeoefening van Coetzee en sy medestanders gekom het, het verband gehou met die wyse waarop die opvoedingsleer deur hulle beoefen is. Hierdie krisis was dus metodologies van aard.7 Coetzee was naamlik 'n tydgenoot van Dooyeweerd, die "vader" van die wysbegeerte van die wetsidee, Vollenhoven en ook Stoker, die "vader" van die wysbegeerte van die skeppingsidee. In die vermelde Inleiding tot die algemene teoretiese opvoedkunde (1965:93 e.v.) behandel Coetzee 'n hele reeks voorteoretiese grondslae van die opvoedkunde wat merkwaardig ooreenkom met die modaliteite of synswyses van die werklikheid en die mens wat deur hierdie twee sistematiese benaderings tot die wysbegeerte geïdentifiseer is. In die bronnelys van die Inleiding toon Coetzee dat hy op die hoogte van die werk van sowel Dooyeweerd en Vollenhoven as Stoker was. Coetzee maak egter nie van die sistematiek van die een of ander vorm van Christelike wysbegeerte gebruik vir die ordening van sy gedagtes nie.

Van Wyk in Potchefstroom en Schoeman in Bloemfontein, laasgenoemde veral onder inspirasie van die plaaslike eksponent van die wysbegeerte van die wetsidee, Strauss (vgl. onder meer sy Inleiding tot die kosmologie, 1978), gaan doelbewus 'n treetjie verder en ontwikkel 'n vorm van opvoedingsfilosofie wat neerkom op 'n herbedinking van die wysbegeerte van die wetsidee vir die doeleindes van die opvoedkunde (Van Wyk, 1973; 1974; 1974b; Schoeman, 1975b). Hierdie nuwe benadering tot die reformatoriese opvoedingsfilosofie in Suid-Afrika behou momentum tot laat in die tagtigerjare toe alle sistematiese benaderings tot die opvoedkunde onder die aanslag van die postmodernisme die wyk moes neem.

Intussen is die krisis vir die reformatoriese opvoedingsfilosofie in Suid-Afrika verder verdiep weens aanvalle en invloede uit ander

$7 \quad$ Coetzee en sy medestanders het wel filosofies-sistematies te werk gegaan in hulle beoefening van die filosofie van die opvoeding, maar hulle het tegelyk ook gebruik gemaak van 'n probleem-gesentreerde benadering. Miskien is die metodologiese "krisis" veroorsaak deur 'n persepsie aan die kant van Van Wyk, Schoeman en andere dat die reformatoriese opvoedingsfilosofie nie "sistematies genoeg" beoefen is nie - 'n persepsie wat versterk is deur onder meer die fenomenoloog Landman se omvattende en hoogs gesistematiseerde ontledings van die opvoedingsverskynsel op daardie stadium. 
oorde. Aan die een kant is die reformatoriese benadering tot die opvoedingsfilosofie vanuit liberaal-Engelstalige kant aangeval oor die Christelik-nasionale inslag daarvan (vgl. Schutte, 1984). 8 Sulke aanvalle het veral gekom van die kant van opvoedkundiges soos Wally Morrow, Linda Chisholm, Penny Enslin, Pam Christie, Peter Kallaway en andere. Aan die ander kant moes dit ook kritiek verduur van buitelandse reformatoriese opvoedingsfilosowe soos Fowler (Fowler, Van Brummelen \& Van Dyk, 1990:137-138) wat van oordeel was dat sekere beoefenaars van die reformatoriese opvoedingsfilosofie in Suid-Afrika onder die dekmantel van 'n apolitiese benadering "failed to address the structural distortion that is the fundamental barrier to the fulfillment of the ... aspirations" van die voorstanders van die "people's education". Hierdie beskuldigings is onderstreep deur eksponente van die destydse "people's education"-beweging soos Van den Heever, Mkhatswa, Stofile, Sizulu en andere (vgl. Van der Walt, 1987; McKay \& Romm, 1992). Die Suid-Afrikaanse vorm van reformatoriese opvoedingsfilosofiebeoefening is daarvan verdink dat dit die politieke doel gehad het om die ideale van die apartheidsbedeling te onderskraag deur Christelik-nasionale onderwys in stand te hou en selfs te bevorder. In die politieke en konstitusionele krisis wat Suid-Afrika op daardie stadium beleef het, het hierdie kritiek die reformatoriese opvoedingsfilosofie in Suid-Afrika in die hart getref. Die geloofwaardigheid van die reformatoriese opvoedingsfilosofie was in die Suid-Afrikaanse samelewing sterk onder verdenking.

Al hierdie krisissituasies het 'n tweërlei resultaat tot gevolg gehad. Aan die een kant het daar toenemend druk gekom om die opvoedingsfilosofie in die algemeen, en die reformatoriese opvoedingsfilosofie in die besonder, in die kurrikulums vir onderwysersopleiding af te skaal of selfs heeltemal te verwyder. Namate opvoedingsfilosowe soos Schoeman, De Vries, Landman,

8 Die saad van hierdie krisis is ook reeds vroeg gelê. Die Christelik-nasionale beginsel is mettertyd deur politieke partye en selfs deur die destydse owerheid gebruik as die filosofiese grondslag en regverdigingsgrond van die politiekstaatkundige beleid van afsonderlike ontwikkeling bekend as apartheid (19481994). Die beginsel van "die handhawing van 'n eie nasionale identiteit" het gaandeweg net op die behoud van die identiteit van blankes betrekking gehad. Die beginsel van "geregtigheid teenoor andere" het gaandeweg uitgekristalliseer tot vorme van territoriale en "klein" apartheid. Die beginsel van "handhawing van eie identiteit" het gaandeweg verskraal tot rasse- en kulturele geskeidenheid, onder meer in die onderwys. In die aanloop tot die nuwe demokratiese bedeling (1976-1994) het hierdie aspekte van die Christelik-nasionale benadering onder hewige druk gekom. 
Van der Walt en andere die tuig neergelê het of in bestuursposisies ingeskuif het, het hierdie afskalings plaasgevind. In die meeste gevalle is daar nie weer opvolgers vir hulle benoem nie, en waar daar wel opvolgers was, het dit hulle aan entoesiasme vir die ontwikkeling van die vakgebied ontbreek weens die vermelde faktore wat die beoefening daarvan in die wiele gery het. Die opvoedingsfilosofie as wetenskap in Suid-Afrika het dus op alle fronte die kreeftegang begin gaan. Waar dit tot ongeveer die begin van die negentigerjare 'n taamlik gewilde studierigting was (daar het elke jaar 'n hele aantal studente gepromoveer), het dit daarna prakties van die agendas van opvoedkundefakulteite verdwyn. Beoefenaars van die vakgebied het óf oorgeskuif na ander dissiplines, of hulle het nie-opvoedingsfilosofiese vraagstukke onder die vaandel van die opvoedingsfilosofie begin ondersoek.

Hierdie tendens is wêreldwyd ook aangevuur deur die postmodernisme. Nie net het die postmoderne benadering die vooruitgangsideaal van die positivisme afgewys nie (Middleton \& Walsh, 1995:15, 19), maar dit het ook sistematiese besinnings oor die opvoeding en enige vorm van voorskriftelike opvoedingsleer ("total scheme of things"-benaderings, vgl. Middleton \& Walsh, 1995:35) toenemend ongewild laat raak. In die plek daarvan het 'n meer perspektiwiese en probleemgerigte benadering tot die lewe en die wetenskap gekom (Middleton \& Walsh, 1995:32; O'Loughlin, 1999:55 e.v.; 2000:55 e.v.). Hierdie benadering het 'n neiging tot 'n individuele en sosiale konstruktivisme in die hand gewerk (Middleton \& Walsh, 1995:37, 50). Postmoderne mense meen dat hulle nie enige sistematiese opvoedingsleer benodig om koers in die lewe of in die opvoeding/onderwys te kan bepaal nie; hulle kan self rigting bepaal of kies (Middleton \& Walsh, 1995:56).

Hierdie tendense is verder aangeblaas deur 'n kultuur van fundamentele menseregte wat in Suid-Afrika in 1994 posgevat het met die aanbreek van die nuwe konstitusionele bedeling. Die hedendaagse mens is nie slegs outonoom (self-bepalend en -wetgewend) nie (Middleton \& Walsh, 1995:51), maar is ook iemand met fundamentele regte. Op hierdie manier het die menseregtekultuur hande gevat met die postmodernistiese tydgees.

Die postmoderne deurbreking van die grense tussen die dissiplines van die opvoedkunde en van kennisgebiede in die algemeen (vgl. Hargreaves, 1994:62 e.v.), bring voorts mee dat prinsipiële besinning oor byvoorbeeld menseregte nie noodwendig in 'n aparte, selfstandige dissipline soos die opvoedingsfilosofie hoef plaas te vind nie. Dit kan goedskiks in ander dissiplines soos die 
onderwysreg, die godsdiensopvoedkunde, die vergelykende opvoedkunde of die "suiwer" filosofie plaasvind. Ook hierdie toedrag van sake maak die opvoedingsfilosofie as 'n aparte dissipline van die opvoedkunde oorbodig - dit maak selfs die uitbouing van die opvoedingsfilosofie as 'n sistematiese kennisgebied onmoontlik.

In die afgelope dekade, dus vanaf 1994 tot op datum, het daar, in terme van Kuhn ([1962] 1970:23 e.v.) se opvatting van hoe die wetenskap ontplooi, nog nie weer 'n stadium van "normale" reformatoriese opvoedingsfilosofiebeoefening aangebreek nie. Soos vermeld, is die Suid-Afrikaanse vorm van reformatoriese opvoedingsfilosofiebeoefening de facto van die agenda geskrap, onder meer deur die sekularisering van selfs universiteite soos dié van die Vrystaat en die voormalige $\mathrm{PU}$ vir $\mathrm{CHO}$ (tans NoordwesUniversiteit, Potchefstroomkampus). Beoefenaars van 'n reformatoriese opvoedingsfilosofie in Suid-Afrika kry tans eerder aansluiting by die denke van buitelanders soos Fowler (Australië), Van Dyk (VSA), Van Brummelen (Kanada), Miedema (Nederland) en selfs Rooms-Katolieke opvoedingsfilosowe soos Smeyers (België) en Zecha (Oostenryk) en andere. Nog ander opvoedingsfilosowe vind 'n heenkome in die suiwer filosofie, met pogings tot die vrugbaarmaking van suiwer filosofiese gedagtes vir die opvoedkunde, byvoorbeeld deur te herbesin oor Klapwijk se Transformationele filosofie (1995) met die oog op 'n kritiese benadering tot teorieë in die opvoedkunde (vgl. Van der Walt, 2002:1994 e.v.). ${ }^{9}$

\section{Neurath se boot}

'n Mens kan ook op ander maniere na die ontplooiing van die wetenskap, in hierdie geval die opvoedingsfilosofie, kyk. Kuhn se opvattings het 'n mens daarna laat kyk in terme van wetenskaplike paradigmas of episteme, tydperke van normale wetenskapsbeoefening, tye van krisisbelewing in en deur paradigmas, en daarna weer voortsetting in die raamwerk van 'n nuwe paradigma as 'n vorm van normale wetenskap.

Die sogenaamde piecemealists het egter op 'n eie manier op Kuhn se gedagtes oor die ontplooiing van die wetenskap voortgebou. Voorbeelde hiervan vind ' $n$ mens in hedendaagse verwysings na

$9 \quad$ Eksponente van die Engels-liberale en van "die people's education"-benadering skyn, na die koms van die demokrasie in 1994, ook in 'n mate hulle struggleagenda kwyt te wees - hulle val ook tans rond om nuwe rigting te kry. 
"Neurath se boot"10: "Ons is soos skepelinge wat hulle skip op die oop see moet herstel, sonder om dit ooit in 'n dok uitmekaar te kan haal en met goeie materiaal te herstel." Die wetenskap is soos ' $n$ seilboot waarvan die planke een na die ander ter see vervang word. Aan die einde van die reis is dit nog dieselfde boot, maar dit is tog ook heeltemal anders. Hierdie siening wyk af van dié van Kuhn in die sin dat dit die ontplooiing van die wetenskap as kontinu sien; dit ontplooi nie noodwendig sprongsgewys as gevolg van krisisse nie, en die vervanging van dele daarvan geskied algaande. Volgens die voorstanders van hierdie siening is die wetenskap 'n entiteit waarvan spesifieke onderdele van nader ondersoek kan word en, indien nodig, vervang kan word. Daar is dus nie sprake van "krisis" en "revolusie" soos Kuhn gemeen het nie (Fuller, 1993:101 e.v.). Die voorstanders van die stuksgewyse benadering tot die ontplooiing van die wetenskap beskou hulself dus as "kontinuïste" (Foucault, 1996:103).

'n Beoordeling van die ontplooiing van die beoefening van die reformatoriese opvoedingsfilosofie sedert Coetzee, toon dat 'n mens inderdaad ook op hierdie manier daarna kan kyk. Die planke van die boot is met die verloop van tyd telkens vervang. Krisisse vir die reformatoriese opvoedingsfilosofie, veroorsaak deur agtereenvolgens die logiese positivisme (insluitende die taal- en konseptuele analise uit die Anglo-Saksiese wêreld), die fenomenologie in die algemeen, maar veral die besondere beoefening daarvan in SuidAfrika self, die liberalisme, die invloed van die wysbegeertes van die wets- en die skeppingsidees, die nuwe politieke situasie in die land sedert 1976, die druk vanuit die postmodernisme en die aanbreek van die menseregtekultuur in Suid-Afrika in 1994, het almal veroorsaak dat planke aan die boot verander moes word. Die ongeluk met die boot van die reformatoriese opvoedingsfilosofie in Suid-Afrika is dat dit weens al hierdie krisisse al kleiner en kleiner geword het, en tans op die punt staan om te verdwyn.

\section{Die situasie tans: die "ekster"-stadium}

Die opvoedingsfilosofie word tans in Suid-Afrika, en ook elders in die wêreld, selde as 'n selfstandige wetenskapsrigting beoefen. Dit kom

10 Otto von Neurath, een van die lede van die Weense Kring, het hierdie metafoor al in 1921 in sy werk Anti-Spengler (Neurath, 1973) gebruik. Die metafoor is onlangs deur verskillende ander denkers, soos Lievers (2003:150) en GodfreySmith (2003:30; vgl. ook Blackburn, 1996:259) weer na vore gebring om te verduidelik hoe wetenskaplike vernuwing stuksgewys kan geskied. 
nog ter sprake in die vorm van "foundational studies" en in die grondslae van ander dissiplines van die opvoedkunde, onder meer in diskussies oor waardeopvoeding (De Klerk, 2000; Van der Walt, 2003; De Klerk \& Rens, 2003). Bydraes word ook gelewer oor die grondslae van allerlei disparate opvoedkundige vraagstukke, naamlik: dissipline (Van der Walt, 2003b; Oosthuizen, Roux \& Van der Walt, 2003); die effektiwiteit van die onderwys (Van der Walt \& Janse van Rensburg, 2001; Van der Walt, 2001); die onderrigleerhandeling (Monteith \& Van der Walt, 2002); opleidingsvoorsiening (Erasmus, Wolhuter, Steyn, Mentz \& Van der Walt, 2002); geborgenheid (Oosthuizen, Mentz \& Van der Walt, 2002) en opvoedkundige futurologie (Van der Walt, 2000). Hierdie bydraes konstitueer egter nie 'n sistematiese uitbouing van die opvoedingsfilosofie as 'n wetenskap nie.

Verklarings vir hierdie toedrag van sake kan in die hedendaagse kultureel-maatskaplike klimaat gevind word. Die laaste twee of drie dekades van wetenskapsbeoefening wêreldwyd word gekenmerk deur die sogenaamde sintetiese of "magpie (ekster) approach" tot teorievorming (Sim \& Van Loon, 2005:6 e.v.). Hierdie benadering word daardeur gekenmerk dat wetenskaplikes teorieë meng en pas ten einde die wetenskaplike taak voorhande te kan uitvoer. Sim en Van Loon (2005:7 e.v., 117 e.v.) tipeer hierdie benadering soos volg:

Except for the most committed enthusiasts of particular movements, most critics tend to operate in magpie fashion these days, selecting a bit of this theory and a bit of that for their own personalized approach.

Die blote aanwesigheid van 'n hele aantal kompeterende teorieë werk hierdie soort benadering in die hand. Ons siening van die wetenskap word verder gekompliseer deur die gebruik van nuwe metafore: teorieë wat groei soos risome, dit wil sê wat soos kommunikasienetwerke uitbrei en hulle eie koers kies verby die bestaande gesagstrukture - die wetenskap wat nomadies van aard is of behoort te wees. Nomadiese denke dui op 'n benadering wat nie gebonde is aan enige besondere denksisteem of bron van gesag nie. Dit erken ook geen grense nie.11

11 Die feit dat die "Sokal-skandaal" in 1996 kon plaasvind, gee 'n aanduiding van die mate waarin die "ekster-benadering" tot absurditeit gedryf kan word. Sokal het, tong in die kies, betoog vir 'n "libertynse vorm van wetenskap". In dié proses het hy gepleit vir vorme van ekstreme relativisme wat aan die absurde gegrens het. En tog is hy ernstig opgeneem deur die keurders van sy artikel vir die 
In hierdie omstandighede is dit dus moeilik om te sien hoedat 'n vorm van opvoedingsfilosofie, gebaseer op 'n sistematiese reformatoriese denkraamwerk, in die afsienbare toekoms weer tot stand gebring sal kan word. Dit sal inderdaad die toewyding van "the most committed enthusiasts" van 'n reformatoriese denkraamwerk verg om dit te bewerkstellig.

\section{Beoordeling en aanbevelings}

Die reformatoriese opvoedingsfilosofie, wat onder die sorg van Coetzee en andere ontwikkel is tot een van die volwaardige dissiplines van die opvoedkunde, het in die afgelope ses dekades so 'n ontplooiingsproses deurloop dat ons vandag die getuies van die einde daarvan kan wees. Die redes hiervoor is duidelik: In die eerste instansie het die reformatoriese opvoedingsfilosowe en opvoedkundefakulteite hulle sig op 'n agenda van werksaamhede verloor in die aangesig van verskeie krisissituasies. Die postmodernisme het besinning oor beginsels nutteloos gemaak, aangesien 'n mensgenormeerde soeke na waardes sterker op die voorgrond getree het. Volgens die postmoderne mens is waardes niks anders as die mens se eie konstruksies nie (Middleton \& Walsh, 1995:58-61), en is nie in vaste beginsels gefundeer nie. Etiese normatiwiteit is in wese 'n kwessie van die mens se keuse. So 'n besinning oor waardes is egter nie gelyk aan die sistematiese en doelgerigte beoefening van die opvoedingsfilosofie nie. In die tweede instansie is die beoefening van die reformatoriese opvoedingsfilosofie nie meer lonend in die nuwe sakegerigte omgewing waarin wetenskaplikes werk nie. Studente sien ook nie meer daarin 'n toekoms nie.

gerespekteerde kritiese tydskrif Social Text. Eers toe hy die redakteurs meedeel dat hy net 'n grap gemaak het, is ingesien hoe belaglik sy argument was. Sokal was naamlik gefrustreerd oor die herhaaldelike misbruik van (natuur-) wetenskaplike konsepte en terminologie in die werk van intellektualiste, en ook oor die ekstreme vorme van epistemiese relativisme wat voortgevloei het uit onkritiese toepassings van Kuhn se paradigma-beskouing (Macey, 2001:358). Hy het onder meer aangevoer dat pi nie 'n konstante is nie, en dus nie universeel van aard is nie, maar relatief aan die posisie van die waarnemer. Daarom is dit onderworpe aan onvermydelike historisiteit! (Sim \& Van Loon, 2005:13-14). Met hierdie absurde argument wou hy toon hoedat sommige denkers onkrities gebruik maak van die mees resente teorieë van die fisika en ander natuurwetenskappe. In Sokal (2003:56) se eie woorde: "My original motivation had to do with epistemic relativism. It seems to me that a sloppily thought-out relativism has become the unexamined Zeitgeist in large sectors of the American humanities and some parts of the social sciences." 
Hierteenoor moet andermaal beklemtoon word dat die wetenskap nie neutraal is nie, maar altyd binne bepaalde denkraamwerke, paradigmas of episteme beoefen word. Die dieptelae van die wetenskap moet as ' $n$ wesenlike deel van wetenskapsbeoefening beskou word. Dit kan van elke opvoedkundige verwag word om aandag te gee aan die kritiese blootlegging van filosofiese en wetenskapsteoretiese aannames en veronderstellings van die teorieë in die onderskeie dissiplines van die opvoedkunde. Dit moet geskied vanuit 'n bepaalde "wetenskaplike lewensbeskoulike perspektief". Alle wetenskaplikes behoort erns te maak met die ondersoek na die dieptedimensies van hulle wetenskapsgebiede (lewensbeskoulike en filosofiese grondslae, vakfilosofiese aspekte en wetenskapsteoretiese of -filosofiese fasette) (Potgieter, 2002). Die verskillende lae van die wetenskap, soos deur Du Plessis (2000) (vgl. Van der Walt, 2002b:16 e.v.) verwoord, is 'n verdere uitbouing van die bydrae op hierdie gebied wat Botha reeds in 1990 gemaak het (Botha, 1990:5 e.v.). Met hierdie wetenskapsteoretiese bydrae is daar ' $n$ besondere taak op die tafel van elke opvoedkundige geplaas.

\section{Slotopmerking}

Die noodsaaklikheid van die beoefening van die opvoedingsfilosofie, onder meer in die vorm van grondslaestudie, het nie verdwyn nie. Dit is nog net so dwingend noodsaaklik om hierdie dissipline te beoefen soos dit in Coetzee se tyd was. Die verwysing na allerlei metafore uit die filosofie en die sosiologie van die wetenskap het die mens in staat gestel om raak te sien hoedat die omstandighede vir die beoefening daarvan ongunstig geraak het. Die tyd het egter nou aangebreek dat daar weer ernstig gekyk moet word na maniere om dit te laat herleef. Daar is soveel probleme op die terrein van die opvoeding, onderwys ${ }^{12}$ en opvoedkunde, dat daar tans wel plek is vir die stelselmatige uitbouing van die opvoedingsfilosofie as 'n volwaardige wetenskap.

12 Met besondere verwysing na die situasie in Suid-Afrika: die ruimte ontbreek om aan te toon hoedat die afskaling van ouerseggenskap en die afwatering van Bybelonderrig in die kurrikulum, om maar net twee belangrike voorbeelde te noem, opnuut besinning vanuit opvoedingsfilosofiese oord noodsaak. 


\section{Geraadpleegde bronne}

BARROW, J.D. 1999. Impossibility: the limits of science and the science of limits. London: Vintage.

BINGLE, H.J.J. 1953. Prof. dr. Johannes Christiaan Coetzee as akademikus. Koers, 20(5):168-172. Opgedra aan prof. J. Chr. Coetzee by geleentheid van sy 60 ste verjaarsdag. Potchefstroom: $\mathrm{PU}$ vir $\mathrm{CHO}$.

BLACKBURN, S. 1996. Dictionary of philosophy. Oxford: Oxford University Press.

BLAKE, N. 1996. The democracy we need: situation, post-foundationalism and enlightenment. Journal of Philosophy of Education, 30(2):215-238.

BOTHA, M.E. 1990. Metateoretiese perspektiewe op die sosiale wetenskappe. Potchefstroom: Sentrale Publikasies. (Reeks A).

COETZEE, J.C. 1939. Die gereformeerde beginsel en die onderwys in Transvaal, 1959-1937. Bloemfontein: Nasionale Pers.

COETZEE, J.C. 1939. Die moderne opvoeding: 'n histories-kritiese studie. Pretoria: Van Schaik.

COETZEE, J.C. 1940. Die eerste beginsels van die Calvinistiese opvoeding. Stellenbosch: Pro Ecclesia. (Die Ossewareeks, no. 2.)

COETZEE, J.C. [1943] 1965. Inleiding tot die algemene teoretiese opvoedkunde. Pretoria: Van Schaik.

DE KLERK, J. 2000. Waarde-uitklaring: Trojaanse perd in Suid-Afrikaanse skole? Koers, 65(3):341-356.

DE KLERK, J. \& RENS, J.A. 2003. The role of values in school discipline. Koers, 68(4):353-372.

DE KLERK, W.J. 1973. Die Calvinisme in perspektief. (In De Klerk, W.J., Duvenage, B. \& Van Wyk, J.H. 1973. Roeping en werklikheid. Potchefstroom: Pro Rege. p. 157-172.)

DE KLERK, W.J. \& DUVENAGE, B. 1973. Sentrale Calvinistiese uitgangspunte. (In De Klerk, W.J., Duvenage, B. \& Van Wyk, J.H. Roeping en werklikheid. Potchefstroom: Pro Rege. p. 173-190.)

DU PLESSIS, P.G.W. 2000. Grondslaestudies - 'n wesenlike deel van ons wetenskapsbedryf. Potchefstroom: Fakulteit Natuurwetenskappe, PU vir $\mathrm{CHO}$. Ongepubliseerde voordrag.

DUVENAGE, B. \& DE KLERK, W.J. 1973. Die Calvinistiese antropologie. (In De Klerk, W.J., Duvenage, B. \& Van Wyk, J.H. Roeping en werklikheid. Potchefstroom: Pro Rege. p. 191-211.)

ERASMUS, J.C., WOLHUTER, C.C., STEYN, S.C., MENTZ, P.J. \& VAN DER WALT, J.L. 2002. Onderwys-/opleidingsvoorsiening en ekonomiese aanvraag. Koers, 67(3):329-350.

FOUCAULT, M. 1966. Les Mots et les Choses. Paris: Gallimard.

FOUCAULT, M. 1996. Questions of method. (In Baynes, K., Bohman, J. \& McCarthy, T. Philosophy: end or transformation? Cambridge: MIT. p. 95117.)

FOWLER, S., VAN BRUMMELEN, H.W. \& VAN DYK, J. 1990. Christian schooling: education for freedom. Potchefstroom: PU vir CHO. (Reeks F.)

FULLER, S. 1993. Philosophy of science and its discontents. New York: The Guilford Press.

GODFREY-SMITH, P. 2003. Theory and reality. Chicago: University of Chicago Press. 
HARGREAVES, A. 1994. Changing teachers, changing times: teachers' work and culture in a postmodern age. London: Cassell.

HORROCKS, C. \& JEVTIC, Z. 2004. Introducing Foucault. Thriplow: Icon Books.

KLAPWIJK, J. 1995. Transformationele filosofie: cultuurpolitieke ideën en de kracht van een inspiratie. Kampen: Kok Agora.

KUHN, T.S. [1962] 1973. The structure of scientific revolutions. Chicago: University of Chicago Press.

KUHN, T.S. 1973. Reflections on my critics. (In Lakatos, I. \& Musgrave, A. Criticism and the growth of knowledge. Cambridge: Cambridge University Press. p. 231-278.)

LANDMAN, W.A. 1974. Leesboek vir die Christen-opvoeder. Pretoria: N.G Kerkboekhandel.

LANDMAN, W.A. \& ROOS, S.G. 1973. Fundamentele pedagogiek en die opvoedingswerklikheid. Durban: Butterworth.

LANDMAN, W.A., ROOS, S.G. \& VAN ROOYEN, R.P. 1974. Die praktykwording van die fundamentele pedagogiek met kernvrae. Johannesburg: Perskor.

LANGEVELD, M.J. 1965. Beknopte theoretische pedagogiek. Groningen: Wolters.

LIEVERS, M. 2003. WVO Quine. (In Doorman, M. \& Pott, H. Filosofen van deze tijd. Amsterdam: Bakker. p. 137-152.)

MACEY, D. 2001. The Penguin dictionary of critical theory. London: Penguin.

MAUTNER, T. 2000. Dictionary of philosophy. London: Penguin.

MCKAY V. \& ROMM, N. 1992. People's education in theoretical perspective. Cape Town: Maskew Miller Longman.

MIDDLETON J.R. \& WALSH, B.J. 1995. Truth is stranger than it used to be. Downers Grove: InterVarsity.

MONTEITH, J.L. DE K. \& VAN DER WALT, J.L. 2002. Epistemologiese oortuigings en die onderrig-leerhandeling. Koers, 67(2):213-228.

NEURATH, O. 1973. Anti-Spengler. (In Neurath, M. \& Cohen, R.S., eds. Empiricism and sociology. Dordrecht: Reidel. p. 158-213.)

O'LOUGHLIN, M. 1999. New research epistemologies in a changing social landscape. Education as Change, 3(1):48-58.

O'LOUGHLIN, M. 2000. Narrative research methodology. Education as Change, 4(1):55-62.

OBERHOLZER, C.K. 1954. Inleiding in die prinsipiële opvoedkunde. Pretoria: Moreau.

OBERHOLZER, C.K. 1968. Prolegomena van 'n prinsipiële pedagogiek. Kaapstad: HAUM.

OOSTHUIZEN, I.J., LE ROUX, J.M. \& VAN DER WALT, J.L. 2003. A classical approach to the restoration of discipline in South African schools. Koers, 68(4):373-390.

OOSTHUIZEN, I.J., MENTZ, P.J. \& VAN DER WALT, J.L. 2002. Die geborgenheid van die onderwyser as voorwaarde vir opvoedende skoolonderwys. Koers, 67(1):27-44..

POTGIETER, P.J.J.S. 2002. Vakfilosofie en grondslaestudie in die fakulteite en skole: werksdokument. Potchefstroom: Sentrum vir Geloof en Wetenskap, $\mathrm{PU}$ vir $\mathrm{CHO}$.

SCHOEMAN, P.G. 1975. Grondtrekke van die fenomenologiese pedagogiek in Suid-Afrika. Bloemfontein: Sacum. 
SCHOEMAN, P.G. 1975b. Grondslae en implikasies van 'n Christelike opvoedingsfilosofie. Bloemfontein: Sacum.

SCHUTTE, B.C. 1984. Christelike onderwys in 'n moontlike stelsel van religieuse en lewensbeskoulike differensiasie in die RSA. Potchefstroom: Departement Fundamentele Opvoedkunde.

SIM, S. \& VAN LOON, B. 2005. Introducing critical theory. Royston: Icon Books.

SNYMAN, J.J. 1953. Prof. J. Chr. Coetzee as opvoedkundige denker. Koers, 20(5):174-176. Opgedra aan prof. J. Chr. Coetzee by geleentheid van sy 60 ste verjaarsdag. $\mathrm{PU}$ vir $\mathrm{CHO}$, April.

SOKAL, A. 2003. Science and relativism. (In Baggini, J. \& Stangroom, J. What philosophers think. London: Continuum. p. 55-64.)

STRAUSS, D.F.M. 1978. Inleiding tot die kosmologie. Bloemfontein: Sacum.

VAN DEN BEUKEL, A. 2000. Natuurwetenschap en geloof: vuur en water? (In Van Kampen, P.J., red. Christendom onwys: 15 wetenschappers over God, geloof en wetenschap. Kampen: Voorhoeve. p. 10-24.)

VAN DER WALT, J.L. 1987. People's education: 'n model vir onderwys in 'n multikulturele samelewing. Potchefstroom: PU vir CHO. (RGN-projek V0018/K. Ongepubliseerde navorsingsverslag.)

VAN DER WALT, J.L. 2000. Opvoeding vir die vroeg-21ste eeu: 'n Christelikopvoedkundige perspektief. Koers, 65(3):357-367.

VAN DER WALT, J.L. 2001. "School effectiveness research" - 'n metateoretiesmetodologiese perspektief. Koers, 66(4):585-602.

VAN DER WALT, J.L. 2002a. Knowledge and science in a changing intellectual climate. Potchefstroom: Centre for Faith and Scholarship.

VAN DER WALT, J.L. 2002b. Scholarship in a changing intellectual climate. Potchefstroom: Centre for Faith and Scholarship.

VAN DER WALT, J.L. 2003a. Die proses van waardeverheldering in die SuidAfrikaanse onderwysopset beoordeel vanuit reformatoriese perspektief. Koers, 68(2 \& 3):125-142.

VAN DER WALT, J.L. 2003b. 'n Beginselgrondslag vir gesag, vryheid, orde en dissipline in die onderwysopset van die vroeg-21ste eeu. Koers, 68(4):331-352.

VAN DER WALT, J.L. \& DEKKER, E.I. 1983. Fundamentele opvoedkunde vir onderwysstudente. Silverton: Promedia.

VAN DER WALT, J.L. \& DU TOIT, S.C. 1992. J. Chr. Coetzee: reformatoriese opvoedkundige. Potchefstroom: PU vir CHO. (Reeks F2.)

VAN DER WALT, J.L. \& JANSE VAN RENSBURG, F.J. 2001. Effektiwiteit en produktiwiteit in die Christen se lewe, werk en besigheid in die lig van Matteus 25:14-30. In die Skriflig, 35(1):61-80.

VAN RENSBURG, C.J.J., LANDMAN, W.A. \& BODENSTEIN, H.C.A. 1994. Basiese begrippe in die opvoedkunde. Halfway House: Orion.

VAN WYK, J.H. 1973. Religie, opvoedkunde en opvoeding. Potchefstroom: Pro Rege.

VAN WYK, J.H. 1974a. Kosmologie, opvoeding en opvoedkunde. Potchefstroom: PU vir CHO. Ongepubliseerde diktaat.

VAN WYK, J.H. 1974b. Die implikasies van 'n Christelike mensbeskouing vir die opvoedkunde en opvoeding. Potchefstroom: PU vir $\mathrm{CHO}$. Ongepubliseerde diktaat.

VAN WYK, J.H. 1979. Strominge in die opvoedingsteorie. Durban: Butterworth. 
Kernbegrippe:

grondslaestudie

J. Chris Coetzee

opvoeding

opvoedingsfilosofie

Key concepts:

education

foundational studies

J. Chris Coetzee

philosophy of education 
